NOTICE: this is the author's version of a work that was accepted for publication in the International Journal of Nursing Studies. Changes resulting from the publishing process, such as editing, corrections, structural formatting, and other quality control mechanisms may not be reflected in this document. Changes may have been made to this work since it was submitted for publication. A definitive version was subsequently published in the International Journal of Nursing Studies, [50(3), March 2013] doi:10.1016/j.jinurstu.2012.06.009

\title{
Best Practices of Formal New Graduate Nurse Transition Programs: An Integrative Review
}

\section{Kathy L. Rush ${ }^{a}$, Monica Adamack ${ }^{b}$, Jason Gordon ${ }^{a}$, Meredith Lilly $^{c}$, and Robert Janke ${ }^{d}$}

${ }^{\text {a }}$ UBC Okanagan School of Nursing, Kelowna, British Columbia, Canada

${ }^{\mathrm{b}}$ Interior Health Authority, Kelowna, British Columbia, Canada

${ }^{\mathrm{c}}$ McMaster University, Hamilton, Ontario, Canada

${ }^{\mathrm{d}}$ UBC Okanagan Library, Kelowna, British Columbia, Canada 
Best Practices of Formal New Graduate Nurse Transition Programs: An Integrative Review

\section{Abstract}

Objectives: The aim of this review was to identify best practices of formal new graduate nurse transition programs. This information would be useful for organizations in their support and development of formal transition programs for newly hired nurses.

Design: An integrative review of the nursing research literature $(2000-2011)$.

Data Sources: The literature search included PubMed (MEDLINE), the Cumulative Index to Nursing and Allied Health Literature (CINAHL), and the Excerpta Medica Database (Embase). Studies that dealt with programs geared towards pre-registration nursing students were removed. At least two researchers evaluated the literature to determine if the article met the inclusion and exclusion criteria. The final number of articles included in this review is 47.

Review Methods: Cooper's (1989) five-stage approach to integrative review guided the process: Problem formulation, data collection, evaluation of data points, data analysis and interpretation, presentation of results.

Results: Transition program literature was examined according to four major themes: Education (preregistration and practice), Support/Satisfaction, Competency and Critical Thinking, and Workplace Environment. This included new graduates' retrospective accounts of their undergraduate education and examination of orientation and formal supports provided beyond the traditional unit orientation period. Transition programs included residencies, internships, mentorships, extended preceptorships, and generic programs. Common elements of programs were a specified resource person(s) for new graduates, mentor (mentorship), formal education, and peer support opportunities. The length, type of education, and supports provided varied considerably amongst programs, yet the presence of a transition program resulted in improved new graduate nurse retention and cost benefits.

Conclusions: The variability in research designs limits the conclusions that can be drawn about best practices in transition programs for new graduate nurses. The presence of a formal new graduate transition program resulted in good retention and improved competency. The stronger evidence suggests 
that new graduate education should focus on practical skill development, preceptors should receive a level of formal training, formal support should be available at least through the difficult six to nine month post-hire period, opportunities for connection with their peers should be provided, and organizations should strive to ensure clinical units with healthy work environments.

Key words: Clinical competence; Education; New Graduate; Nurse; Personnel selection; Personnel turnover; Staff development; Transition

\section{Statements of:}

What is already known about the topic?

- Evidence of a theory-practice gap and a developmental lag between being a student and entering the workplace

- Transition to practice associated with a reality shock

- Programs as a whole and their constituent components have not been extensively studied in a systematic manner to determine their efficacy or cost-effectiveness

What this paper adds?

- Transition programs have a positive impact on new graduate nurse retention

- Trained preceptors positively influence the new graduate-preceptor relationship

- Mentors, peers, and a transition program of at least 9 months provide new graduates with significant support during transition

- Evidence was variable, and overall of low quality, limiting best practices recommendations 


\section{Best Practices of Formal New Graduate Transition Programs: An Integrative Review Background}

The nursing shortage has drawn national and international attention to the recruitment and retention of new nurse graduates. The attrition rate in Canadian Registered Nurse (RN) entry-to-practice programs is $28 \%$ (Canadian Nurses Association, 2007). This can have a significant financial impact on an organization as considerable resources, in some cases estimated to be $\$ 40,000$ USD per new graduate (Almada et al., 2004), are committed to the recruiting, hiring, orientating, preceptoring, and training of the new graduate. Further, Canadian figures estimate a shortage of 60,000 RNs by 2022 (Canadian Nurses Association, 2007), and the United States (US) National Center for Health Workforce Analysis (2002) predicts the shortage of registered nurses will grow from $12 \%$ in 2010 to $20 \%$ by 2015 .

Central to recruitment and retention concerns has been new graduate nurses' transition to practice, heightened by the movement of nursing education into universities, the growing acuity and complexity of care, and technological advancements. Evidence of a theory-practice gap has been identified as a global phenomenon (Maben et al., 2006). Findings from two recent Canadian studies of practice readiness agreed that a significant and problematic developmental lag exists between being a student and entering the workplace as a graduate nurse (Romyn et al., 2009; Wolff et al., 2010). Further, differing expectations between educational and practice stakeholders were observed, often influenced by the historical and social context within which nursing education and professional practice were grounded (Wolfe et al., 2010).

The entry-level competencies of new nurses have been well documented (College of Registered Nurses of British Columbia, 2010) yet research reveals gaps in their role-related knowledge, skills, and clinical judgment. Del Bueno (2005) found that new graduates from across the United States lacked critical thinking, with aggregate data revealing that $65 \%$ to $76 \%$ did not meet expectations for entry-level clinical judgment ability. In a Swedish study of competence of newly graduated nurses', neophyte nurses were rated lowest in the areas of informing and teaching co-workers and students and planning and prioritizing nursing interventions (Lofmark et al., 2006). Further, near misses and omissions and errors in the performance of clinical skills such as post-operative ambulation and wound dressing changes have been documented (Bjork and Kirkevold, 1999). 
There is a plethora of literature on the transition of the new nurse graduate to practice, dating back to Kramer's (1974) seminal work on the nature of this transition as a reality shock. Various facets of this transition have been studied including new graduates' perceptions and experiences of the transition (Goh and Watt, 2003), support (Johnstone et al., 2008), competence (Lofmark et al.; Ramritu and Barnard, 2001), retention (Altier and Krsek, 2006), job satisfaction (Altier and Krsek, 2006), the workplace environment (Lavoie-Tremblay et al., 2008) and organizational infrastructure (Schoessler and Waldo, 2006). In addition, new Graduate Transition models have been developed that capture this very unique developmental process (Boychuk-Duchscher, 2009).

Transitional programs have emerged to facilitate and support the development and integration of neophytes into the workplace. Proponents of these programs regard them as essential for new graduates and in some countries this has led to the development of national standardized new graduate transition programs such as the US National Council of Nursing's Regulatory Model for Transitioning New Nurses to Practice (Roxburgh, et al., 2010) and Scotland's Flying Start Program (Spector and Echternacht, 2010). Others question the need for these programs, contending that new graduates should be prepared to meet the expectations of the workplace. Referred to as transition support programs, new graduate programs, residencies, or internships, transition programs have been characterized by diversity in duration, structure, content, and financial support. The length, number, and type of clinical rotations vary, as do the range of program components. Components generally include a combination of the following: education, formal or informal preceptorships, mentorships, supernumerary time, and unit specific orientation. Although transitional programs have been implemented across a range of practice settings, including home care (Meadows, 2009), the bulk of the transitional work has occurred with new graduates integrating into the acute care workplace, where $60 \%$ of new graduates choose to practice (Canadian Institute of Health Information, 2006).

Evidence has been mixed in demonstrating the value of these programs (Evans, 2008). In a review of new graduate programs, Levett-Jones and FitzGerald (2005) concluded that both the programs as a whole and their constituent components have not been studied in a systematic, comprehensive or objective manner to determine their efficacy or cost-effectiveness. Although case exemplars of new graduate transition initiatives reported in the literature provide descriptions of program components, those 
components that most strongly contribute to program results have not been identified. Despite the volume of work done in this area there has been little consensus regarding what constitutes best practice. Therefore, the purpose of this study was to review existing research literature to identify best practices of formal new graduate nurse transition programs.

\section{Methodology}

Cooper's (1989) five-stage approach to integrative review guided the process. Following the first stage of problem formulation ensued data collection, evaluation of data points, data analysis and interpretation, and presentation of results.

\section{Data Collection}

The search strategy was developed and conducted in close collaboration with a research librarian at the University of British Columbia. Library databases that were searched included PubMed (MEDLINE), the Cumulative Index to Nursing and Allied Health Literature (CINAHL), and the Excerpta Medica Database (Embase). Key words, relevant synonyms, and associated truncations that were used in the search included new nurse graduates and either transition programs or orientation programs. This review included only English-language studies published between 2000 and 2011, and initial search results yielded more than 3,000 papers.

Studies that dealt with programs geared towards pre-registration students were removed. After duplicate citations were removed, a total of 695 original relevant citations were retrieved via these databases. Citation abstracts were reviewed and those not meeting the inclusion criteria were deleted ( $\mathrm{n}$ = 536), leaving 159 papers for potential inclusion in the review. Hand searching of reference lists from these papers was conducted to ensure all relevant papers were included in the review, with four additional papers added.

\section{Evaluation of Data Points}

All 163 articles identified for potential inclusion were then evaluated by at least two researchers to determine if the article met all of the following criteria: (a) based on empirical research; (b) included an abstract; (c) targeted new graduates within one year of graduation participating in a formal new graduate nurse transition program; (d) contained sufficient detail describing the formal new graduate nurse transition program; (e) focused on acute care settings; (f) published in English. Reviewers excluded 
articles for one or more of the following reasons: (a) focused on professional identity (eg. burnout, etc); (b) presented a review of the literature or editorial, or grey literature (c) studied nurses in residential, rural or community settings, (d) included populations other than newly graduated nurses, (e) focused on nurses working in specialty areas that typically provide advanced training. The final number of articles included in this review is 47 .

\section{Data Analysis and Interpretation}

There were frequent consultations and meetings amongst members of the research team regarding elements of the process, such as search strategies, collection tools, and inclusion/exclusion criteria. One of the most significant challenges within the literature was the lack of consistency and clarity regarding definitions of key terms. This was particularly evident regarding the use of the terms 'orientation' and 'transition.' For the purpose of this review, orientation was defined as a period to familiarize staff with a new work environment, related expectations, and policies, and included clinical support through a supernumerary period. A transition program was defined as a program that occurred in addition to a general and/or specific unit orientation and was designed specifically to assist new nurse graduates with their transition to practice. The orientation period is addressed in this review only if it was discussed as a phase of a formal new graduate transition program.

A standardized charting form was developed that included significant elements for extraction from each of the selected papers. Using RefWorks, a bibliographic management tool, papers were categorized depending on their focus according to four major themes: Education (pre-registration and practice), Support/Satisfaction, Competency and Critical Thinking, and Workplace Environment. Papers were reviewed for study design, sample size, program elements (eg. orientation length, transition length, education, supports), and outcomes (eg. competency, critical thinking, job satisfaction). More detail on each transition program is provided in Table 1.

In addition, each paper was scored for its levels of evidence using an adaptation of a system developed by Beck (2001) and later modified by Park and Jones (2010). Three criteria were used that could be extracted from all of the papers and included: Study design (Quasi-experimental = 3 points; Longitudinal $=2$ points; Descriptive and Qualitative $=1$ point); Sample size (Greater than $100=3$ points; $50-100=2$ points; $0-50=1$ point); and Author (Multiple publications $(>3)$ in the transition program 
literature $=2$ points; Limited number of publications within the transition program literature $=1$ point). The result was a level of evidence score specific to each article from 3 (lowest level) to 8 (highest level). Papers with levels of evidence scores from 6 to $8(n=10)$ were considered to be strong. Two authors independently scored the studies with good inter-rater agreement (fixed-marginal kappa score of 0.81 ). The level of evidence score for each article can be found in table 1.

\section{Presentation of Results}

Sample sizes of study populations researched in the papers reviewed ranged from 10 to 7,907 , with a median of 387 . The majority used descriptive designs $(n=27)$, but quasi-experimental $(n=8)$, qualitative $(n=5)$, and longitudinal $(n=7)$ designs were also represented. The vast majority of the literature was of U.S. origin. The literature review revealed both generic transition programs $(n=14)$, and programs based on a specific model: Extended Preceptorship ( $n=11)$, Mentorship $(n=7)$, Residency $(n=13)$, and Internship $(\mathrm{n}=2)$. The Residency literature was dominated by contributions from a U.S. national post baccalaureate nurse residency program established by members of the University Health System Consortium/American Association of Colleges of Nursing partnership (Altier \& Krsek, 2006; Casey et al., 2004; Fink et al., 2008; Goode et al., 2009; Krugman et al., 2006; Pine \& Tart, 2007).

Transition programs varied in length from less than one month to over a year, with 14 papers not specifically identifying a program length. Of the 33 papers that identified a program length, eight had lengths of three months or less, five papers reported lengths from four to six months, and nineteen papers described programs longer than six months. One investigation involved a mix of new graduates in programs from zero to three months and from four to six months in length.

\section{Common Features of Transition Programs}

Due to the variability among programs described in the literature demonstrating positive outcomes, it can be challenging to determine what is most effective. Thus the transition programs in the literature were analyzed for common components.

A defined resource person. The most prevalent component shared by transition programs was the availability of a defined new graduate resource person assigned in a one-to-one relationship with the new graduate. Although this resource person was identified in 15 articles, a standard definition of this role and title was lacking. For example, in some cases the preceptor fulfilled this additional support role 
(Kowalski and Cross, 2010; Schoessler and Waldo, 2006), but in the majority of studies this resource person was described as a Mentor $(n=11)$, 'Clinical Coach,' $(n=3)$ or 'Sponsor,' $(n=1)$. In some cases the resource person started their relationship with the new graduate immediately upon hire, and in other cases the relationship did not begin until after a preceptored period. Beecroft et al. (2006) distinguished the non-clinical, non-evaluative role of the resource person with the clinical supervisory role of the preceptor. Regardless of the title, this additional support person was intended to focus on the socialization of the new graduate (Zucker et al., 2006).

There were an additional five studies that identified the use of a single resource person to support multiple new graduates as an alternate model of support. Titles commonly used to identify this resource included 'Resident Facilitator' or 'Transition Program Coordinator,' whose role was to connect with new graduates and respond to any issues or concerns. None of these roles were specifically evaluated within the literature.

Mentorship. Mentorship was a common type of one-to-one resource available for new graduates within a formal new graduate transition program, but evaluations and outcomes were generally limited to retention. All articles involving mentorship programs demonstrated enhanced new graduate nurse retention (Ho, 2006; Mills and Mullins, 2008). There was limited discussion of mentor selection criteria and matching (Fox, 2010), and only two articles discussed mentor training programs with little detail regarding the content delivered (Fox, 2010; Zucker et al., 2006). The effectiveness of mentor training, the selection process, and the matching process were not specifically assessed. Several programs had salary bonuses for mentors tied to the successful retention of new graduates (Fox, 2010; Zucker et al., 2006). Beecroft et al. (2006) demonstrated that regular meetings with a mentor positively influenced the likelihood of the mentor being a stress reducer $(p=0.001)$, and a source of guidance and support $(p=<0.001)$, and the mentee 'clicking' with the mentor $(p=<0.001)$. In addition, mentors of an older age were more likely to be stress reducers $(p=0.005)$ and to provide guidance and support $(p=0.100)$. Fox (2010) described a structured mentorship program where effectiveness was inferred through evaluation of new graduates' level of satisfaction rating to the statement: 'Overall, I feel confident my job will be satisfying one year from now.' Seventy-five percent of the pilot group mentor-protégé pairs improved their satisfaction score level from 'agree' to 'strongly agree' or from 'tend to disagree' to 'agree.' 
Peer support opportunities. Peer support and providing opportunities for new graduates to meet and discuss their transition experiences with each other was a theme in four qualitative articles. Keller et al. (2006) described a residency program that had as a component various activities designed for the socialization of the new nurse such as welcome breakfasts, lunches, and seasonal parties. Qualitative data collected from new graduates described how this camaraderie assisted with their ability to cope with the stress and emotions experienced during transition. Fink et al. (2008) found peer support and camaraderie as two of the top satisfying aspects of new graduates' work environment. Subjective comments from the new graduates in this investigation included how important the interactions with other residents were, and how this offered moral support.

\section{Impact on New Graduate Retention}

Retention and turnover were important outcomes found in the new graduate transition program literature. A summary of studies that measured these outcomes is provided in Table 2. Retention rates indicated the number or percentage of new graduates remaining at an organization at the end of a defined period. Turnover rates represented a calculated percentage of the number of new graduates leaving an organization within 12 months of their hire date divided by the number of new graduates hired during that same time period. Organizations strive for a high retention rate and a low turnover rate.

Thirteen papers examined new graduate retention rates, six reporting pre- and post-program rates, and the remaining seven providing post-program rates only. Three were investigations utilizing quasi-experimental methodology. Of the four papers investigating new graduate turnover rates, half reported pre- and post-program rates, while the other half reported post-program rates only. In studies that examined pre- and post- program rates, every program resulted in improved retention or turnover figures. The thirteen papers that investigated new graduate retention had on average a rate of $90.1 \%$, and the papers that examined turnover had on average a rate of $10.5 \%$. These figures compare favorably to the Canadian new graduate attrition rate of $28 \%$ (Canadian Nurses Association, 2007), and U.S. national new graduate retention rates that on average range from $55 \%$ to $61 \%$ (Casey et al., 2004).

\section{Cost Benefit of Transition Programs}

Nine articles in the review reported that having a transition program resulted in a cost-benefit for the agency due to improved new graduate retention and decreased turnover. Four reported actual per 
capita cost figures, and seven provided cost-savings information. However, although actual numerical figures were reported, the process for obtaining the figures was rarely detailed.

Transition program costs ranged from a low of $\$ 2,023.91$ to a high of $\$ 12,125$ US per new graduate (Adlam et al., 2009; Bratt, 2009; Fox, 2010; Pine and Tart, 2007). Figures regarding costsavings from a transition program as a result of improved new graduate retention or turnover were provided by Fox (2010) who indicated an annual savings of $\$ 1,040,153$ US (organizational new graduate turnover improved from $32 \%$ to $16 \%$ ), Marcum and West (2004) who reported a $\$ 330,481$ US annual return on investment (organizational new graduate retention improved from $60 \%$ to $89 \%$ ), Lee et al. (2009) who stated their program resulted in a savings of $\$ 186,102$ US over a six month period (no specific retention or turnover data provided), and Pine and Tart (2007) who reported a cost savings of $\$ 823,680$ (new graduate turnover improved from $50 \%$ to $13 \%$ ). Other studies providing estimated savings as a result of new graduate transition programs included Mills and Mullins (2008), who stated improved new graduate retention resulted in a three year cost savings of from 1.4 to 5.8 million dollars (based on their assumption that it costs 1.5 to 2 times a nurse's salary for an organization to recruit and orient a new nurse), Zucker et al. (2006), who indicated that every new nurse retained saves an organization $\$ 40,000$ US or more, and Krugman et al. (2006), who reported data that demonstrated the average budget for managing their annual program is less than the cost to advertise and recruit two nurses.

\section{Education (pre-registration)}

Four articles that addressed retrospectively new graduates' undergraduate education were identified in the literature. A large US survey study of Healthcare agency administrators $(n=410)$ and new graduates $(n=7,497)$ identified that stronger nursing preparation programs appeared to include common education elements. These included faculty that taught didactic content and clinical activities, used information technology and evidence-based practice, integrated pathophysiology and critical thinking throughout the curriculum, and had content related to the care of specific client populations (eg. medicalsurgical clients, clients with psychiatric disorders), and women's health as independent courses (Li and Kenward, 2006). 
Three articles in the review focused on partnership models between educational institutions and healthcare organizations. An important outcome of partnerships between nursing education academic programs and healthcare organizations was the creation of human resources support. This support took a variety of forms including additional clinical practicum opportunities (Campbell et al., 2001), academic involvement in preceptor education (Pickens and Fargotstein, 2006), and access to academic offerings by staff (Roche et al., 2004). An additional benefit of these partnerships was improved new graduate nurse retention (Pickens and Fargotstein, 2006; Roche et al., 2004).

\section{Education (practice)}

Education opportunities during a formal transition program were described in thirteen articles. Education opportunities were delivered during, and at points beyond, unit specific orientation periods but few were specifically evaluated. Only two of the thirteen papers (Blanzola et al., 2004; Young et al., 2008), provided a breakdown of the time spent on each component (e.g. hours spent on practical education vs. hours spent on theoretical classroom type learning). Education was typically delivered via course work and classroom sessions and included clinical practice topics such as pain management, end-of-life care, medication errors, supporting the family during crisis, and pathophysiology (Blanzola et al., 2004; Gavlak, 2007; Strauss, 2009; Beyea et al., 2007). Further into the transition programs, professional development topics included managing the complex patient, conflict resolution, actionoriented learning, and leadership (Blanzola et al., 2004; Keller et al., 2006; Schoessler and Waldo, 2006). A 12-week transition program that included weekly human patient simulation as one component, in addition to weekly didactic sessions and preceptored time, enhanced new graduate confidence, competence, and readiness for independent practice (Beyea et al., 2007). Other education strategies and learning opportunities included journal assignments and professional portfolios but these were not well evaluated (Forneris and Peder-McAlpine, 2009; Keller et al., 2006).

\section{Support/Satisfaction}

The initial support provided to new graduates typically occurs during an orientation period, and is primarily provided by a preceptored experience. An orientation component is specifically described in eighteen papers within the transition program literature with periods ranging in length from less than 4 weeks to more than three months, and with preceptorship as a strong theme. An overwhelming majority 
of the papers made specific reference to the importance of preceptorship and incorporated dedicated preceptored shifts, however, details were lacking about specific components such as if all shifts were preceptored for the entire unit orientation period. Seven studies discussed the importance of preceptors receiving formal education and reported outcomes that included enhanced preceptor satisfaction (Beecroft et al., 2008), preceptor retention (Baggot et al., 2005), improvement in new graduate critical thinking $(p<0.05)$ (Sorensen and Yankech, 2008), quality care (Lee et al., 2009), new graduate satisfaction with their preceptored experience (Baggot, et al., 2005), and new graduate retention (Pickens and Fargotstein, 2006). There was considerable variation in the length of preceptor training programs (from 3 hours to 3 days) and delivery methods. Common elements of preceptor training programs included adult learning principles, learning styles, conflict resolution, and Benner's (1984) novice to expert transition framework. Although the importance of preceptor matching was mentioned in two articles, there were no measurable outcomes. Nugent's (2008) qualitative investigation of 150 new graduates revealed that being assigned to different preceptors was difficult for some, but many new graduates also found this beneficial as it provided exposure to different approaches to prioritizing care and time management. Four of the eighteen articles discussing orientation within the transition program literature made specific reference to the use of 'supernumerary time,' or time to become immersed in their new role without workload pressures (Adlam et al., 2009). Supernumerary time ranged in length from 3 weeks (Leigh et al., 2005) to four months (Murphy et al., 2004), with one recommendation for 6 weeks as the ideal length (Adlam et al., 2009).

Increases in retention, job satisfaction, and comfort with skills are outcomes that have been reported in conjunction with orientation within a transition program. Longer orientation was shown in one US study $(n=329)$ to decrease turnover rates. New graduates who had already left their first nursing job had on average an orientation two weeks less than new graduates who had not left their first nursing job (Scott et al., 2008). Further, new graduates who received a longer orientation that met all of their needs were more satisfied in their current position. Casey et al. (2004) demonstrated that $96 \%$ of new graduates $(n=270)$ were not comfortable performing skills and procedures typically conducted by nurses during the orientation period. An orientation that included dedicated time for practicing specific skills (e.g. code blue, chest tubes, and advanced parenteral therapy) increased comfort with skill performance 
(Gavlak, 2007). In another survey study ( $n=434)$ open-ended qualitative comments from new graduates revealed that orientation could be improved by including fewer formal classes (Fink et al., 2008).

New graduate satisfaction was examined in several studies and typically measured via self-report or inferred based on other variables such as retention. Bratt (2009) surveyed 1,100 new graduate nurses who participated in a nurse residency program in Wisconsin. The time period from six to nine months after hire was associated with the highest levels of stress, and the lowest levels of job satisfaction and organizational commitment. Both Krugman et al. (2006) and Williams et al. (2007) found that satisfaction decreased during the initial transition phase, but this was followed by a significant increase in satisfaction at the end of the one-year transition period $(p<0.05)$. The authors suggest these findings reflect that new graduates experience an initial level of reality shock during their transition to practice, but emerge from it towards the end of their residency. They conclude that new graduates may be vulnerable during the period around 6 months, and transition programs that end before one year may not provide sufficient support or time for new graduates to adjust. This finding is further supported by Casey et al.'s (2004) exploration of qualitative data in that nurses in the second six months of a residency program had higher job satisfaction ratings than in the first six months.

\section{Competency and Critical Thinking.}

Themes of competency and critical thinking were evident in all phases of new graduate transition, including retrospective examinations of undergraduate education. Six articles described new graduates' perceptions of their academic entry-level program's ability to prepare them for practice. A lack of preparation in the following areas was reported: administering medications to groups of clients (Li and Kenward, 2006; Smith and Crawford, 2003); pharmacology (Rydon et al., 2008); and nurse-physician interactions (Casey et al., 2004; Li and Kenward, 2006). Qualitative investigations noted that many groups of nurses - experienced practitioners, ward managers, and new graduates themselves - all felt that new graduates were not ready for independent practice on registration (Clark and Holmes, 2007). New gradates also felt there was a deficiency in clinical practice opportunities during undergraduate education (Ellerton and Gregor, 2003). The integration of critical thinking skills in nursing education programs has grown with the recognition that students cannot be prepared for every situation they may encounter in clinical practice (Kaddoura, 2010). Two studies from the transition program literature 
investigated problem-based learning compared to traditional curriculum. New graduates educated via problem-based learning were able to solve problems with greater competency than those trained via traditional methods (Uys et al., 2004). Less than $5 \%$ of new graduates educated via traditional methods perceived their education to promote critical thinking skills (Applin et al., 2011).

The transition literature that addressed competency beyond the point of hire measured it differently across studies using both standardized and researcher developed tools. Standardized tools utilized to measure competency included the Performance Based Development System (Anthony and del Beuno, 2001), the Professional Judgment Rating Form (Facione et al., 1998), and the Casey-Fink Graduate Nurse Experience (Goode et al., 2009). Increased competency was found regardless of rater (self, peer, preceptor, manager, or administrator), duration, or type of transition program (Beyea et al., 2007; Goode et al., 2009; Komaratat and Oumtanee, 2009).

A qualitative investigation found new graduates $(n=9)$ did not feel fully independent about their nursing work until after they had completed the one-year transition program (McKenna and Newton, 2008). New graduate nurses "did not see themselves as fully fledged registered nurses during the graduate program, rather they were 'graduates' somewhere between student and registered nurse" ( $p$. 14). The authors concluded that the new graduate program acts as a shelter or umbrella.

Closely linked with competence in this body of literature is the new graduate's level of confidence. There is evidence to suggest a lack of confidence can negatively impact critical thinking and reasoning abilities (Haffer and Raingruber, 1998). Fourteen articles addressed the impact of a transition program on new graduate confidence, but there was no evidence of a standardized tool that specifically measured confidence. In the vast majority of cases, improved confidence was inferred by the author based on other outcomes such as retention (Blanzola et al., 2004), decreased level of anxiety (Kowalski and Cross, 2010, $p=0.004$ ), or emerged as a theme from qualitative data (Fink et al., 2008; Hayes and Scott, 2007; Beyea et al., 2007). 


\section{Workplace Environment}

Workplace environment is a significant factor potentially impacting new graduate nurse transition, yet it is not heavily studied in the context of a formal transition program. The most comprehensive investigation regarding new graduate nurses $(n=371)$ in a transition program and their workplace environment utilized a standardized tool to rank the health of the work environments of clinical units employing new graduates (Kramer et al., 2011). Results demonstrated that new graduates working on clinical units with work environments identified as 'Healthy' or 'Very Healthy' experienced less reality shock as they transitioned to practice than new graduates working on clinical units that 'Needed Improvement.' Also, new graduates working at academic-teaching hospitals anticipated higher quality work environments than their colleagues employed at other hospitals.

Anderson et al. (2009) investigated work place environment and its impact on new graduate job satisfaction in a group of 90 new graduates involved in an interactive nurse residency program. Qualitative data from the survey was classified into themes that described work environment 'satisfiers' as helping people and teamwork, and work 'dis-satisfiers' as poor teamwork, physician disrespect, and staffing/scheduling. Casey et al.'s (2004) investigation of qualitative data from new graduates in a transition program shed further light on workplace environment challenges faced during transition. New graduates described a lack of acceptance and respect, and an insensitivity of experienced nurses to their needs for continued development in time management skills.

\section{Discussion}

The $21 \%$ of literature in this review rated as strong evidence contributes more weight to the discussion and study conclusions. However, the number of conclusions that can be drawn about best practices in transition programs for new graduates was limited due to the overall variability in research designs and sample sizes. Few studies had designs with the degree of control necessary to rule out competing explanations. Although there was an overall lack of outcome measures in this area of study evidence shows benefit in selected areas of new graduate transition.

Improved new graduate retention as the result of a transition program was a well-supported theme, however, there were few rigorous designs comparing new graduate retention pre- and postimplementation of a transition program. There was also variability in measures utilized such as retention 
rate, turnover rate, and attrition rate, with no evidence of a standardized definition or formula used when programs and organizations calculate these values. Consistency in the measurement of new graduate retention across provinces and states and national reporting would allow comparison across programs and identification of transition components that facilitate retention. The literature discussing the financial aspects of transition programs was similarly challenged by a lack of consistency in measurement, likely contributing to the broad range of findings regarding cost per capita and return on investment of transition programs.

Academic preparation, although not an emphasis of this review, was addressed in papers rated as weaker in evidence and accessed through new graduates' retrospective accounts that revealed their perceived lack of preparation in specific areas of practice. Education delivered to new graduates during their transition program typically occurred during the orientation period and by various delivery methods, although new graduates identified a preference for hands on education rather than formal classes. There was little discussion about why specific topics were selected, when in the transition program they should be delivered, and with what method of delivery. Dedicated time for skill practice and human patient simulation may hold promise in the development of new graduate competency, but within the context of a transition program need to be investigated in a more rigorous manner.

Support across the trajectory of new graduate transition typically consists of some form of "people support,' and the preceptor is the first person to assume this support role. The evidence suggests several positive outcomes related to the new graduate-preceptor relationship, particularly when the preceptor receives a level of formal training. Other 'people resources' with a role in supporting new graduate transition included mentors, clinical coaches, transition program coordinators, and new graduate peers. Only the use of mentors was extensively evaluated, and there is some strong evidence to suggest mentors can be effective stress reducers and provide guidance and support in a transition program. Subjective reports from some of the qualitative investigations in this review revealed new graduates value the moral support provided by peer-support opportunities. The unit orientation phase of a transition program is when support is quite concentrated, yet the current evidence is inconclusive regarding recommended unit orientation length. There was some weaker evidence to suggest longer orientations resulted in better retention and new graduate satisfaction. Beyond unit orientation there was evidence to 
suggest new graduates struggle with high levels of stress and low levels of job satisfaction in the period six to nine months post-hire, thus some level of support should be available to new graduates at least through this period. Differences in transition and needs for support between Baccalaureate and Associate degree nurses is another area of potential inquiry.

In general, many commonly addressed variables such as job satisfaction, confidence, and competency were measured via self-report, preceptor report, or inferred on the basis of another variable (i.e. satisfaction $=$ retention). There are standardized tools available to measure such variables, and these were utilized by some of the stronger papers within this review. The timing of measurement and its interaction with new graduate nurses' consolidation of knowledge, skills and judgments bears further study.

Work environment is a significant variable impacting new graduate transition. Healthy work environments decrease new graduate reality shock and facilitate transition. It is critical for clinical units to foster such healthy work environments through the establishment of collegial/collaborative relationships with physicians and other disciplines. Healthy units enable nurses to work with other competent nurses in controlling the context in which nursing is practiced, and in functioning autonomously for the benefit of the patient (Kramer et al., 2011). Further, new graduates still experience a lack of acceptance and respect, and an insensitivity of experienced nurses to their needs for continued development in time management skills.

\section{Future Research Recommendations}

It is recommended that further research in the area of new graduate transition include more rigorous study designs. For example, there is a need for longitudinal studies to track the outcomes of transition programs over time and experimental investigations to clearly identify the benefits of a transition program compared to not providing such formal support. Further investigation to conclusively demonstrate a positive return on investment is necessary to validate for funding sources the importance of formal new graduate transition programs. The potential for partnerships between academia and agencies to facilitate smooth transition holds promise, but would benefit from attention to both process and outcomes measurements to appraise the impact. 
Strong investigations evaluating the various components of transition programs are also warranted, such as the impact of other people supports (e.g. Transition Program Coordinators) and the type, delivery method, and timing of education opportunities. Continued study regarding orientation length, supernumerary periods, and the structure of preceptor support within new graduate transition programs would also be beneficial. To clearly identify evidence for best practice this future work should clarify conceptual ambiguity between program components such as the interchangeable use of orientation and transition program, and preceptorship and mentorship. Lastly, evidence-based strategies to improve clinical unit work environments would be very constructive for units employing new graduates.

\section{Conclusions}

There were few rigorously designed studies regarding transition but a strong theme throughout the literature was that formal transition programs improved retention. Further, new graduates benefit from the use of mentors to provide support and from the availability of peer-support opportunities. Preceptors should receive a level of formal training prior to working with a new graduate, and transition programs should provide support for at least 9 months to assist new graduates through a particularly difficult period of stress and decreased job satisfaction. Nursing stakeholders need to continue to work on improving the clinical unit work environments to make them more amenable to new graduate transition. 


\section{References}

Adlam, K.A., Dotchin, M., Hayward, S., 2009. Nursing first year of practice, past, present and future: documenting the journey in New Zealand. Journal of Nursing Management 17 (5), 570-575.

Almada, P., Carafoli, K., Flattery, J.B., French, D.A., McNamara, M., 2004. Improving the retention rate of newly graduated nurses. Journal for Nurses in Staff Development 20 (6), 268-273.

Altier, M.E., Krsek, C.A., 2006. Effects of a 1-year residency program on job satisfaction and retention of new graduate nurses. Journal for Nurses in Staff Development 22 (2), 70-77

Anderson, T., Linden, L., Allen, M., Gibbs, E., 2009. New graduate RN work satisfaction after completing an interactive nurse residency. The Journal of Nursing Administration 39 (4), 165-169.

Anthony, C.E., del Bueno, D. (1993). A performance-based development system. Nursing Management 24 (6), 32-34.

Applin, H., Williams, B., Day, R., Buro, K., 2011. A comparison of competencies between problem-based learning and non-problem-based graduate nurses. Nurse Education Today 31 (2), 129-134.

Baggot, D.M., Hensinger, B., Parry, J., Valdes, M.S., Zaim, S., 2005. The new hire/preceptor experience: cost-benefit analysis of one retention strategy. The Journal of Nursing Administration 35 (3), 138145.

Beck, C.T., 2001. Predictors of postpartum depression: An update. Nursing Research 50 (5), 275-285.

Beecroft, P., Hernandez, A.M., Reid, D., 2008. Team preceptorships: a new approach for precepting new nurses. Journal for Nurses in Staff Development 24 (4), 143-150.

Beecroft, P.C., Santner, S., Lacy, M.L., Kunzman, L., Dorey, F., 2006. New graduate nurses' perceptions of mentoring: six-year programme evaluation. Journal of Advanced Nursing 55 (6), 736-747.

Benner, P., 1984. From novice to expert: excellence and power in clinical nursing practice. AddisonWesley, Menlo Park.

Beyea, S., von Reyn, L., \& Slattery, M.J., 2007. A nurse residency program for competency development using human patient simulation. Journal for Nurses in Staff Development, 23 (2), 77-82.

Bjork, I.T., Kirkevold, M., 1999. Issues in nurses' practical skill development in the clinical setting. Journal of Nursing Care Quality 14 (1), 72-84. 
Blanzola, C., Lindeman, R., King, M.L., 2004. Nurse internship pathway to clinical comfort, confidence, and competency. Journal for Nurses in Staff Development 20 (1), 27-37.

Boychuk-Duchscher, J. B., 2009. Transition shock: the initial stage of role adaptation for newly graduated Registered Nurses. Journal of Advanced Nursing 65 (5), 1103-1113.

Bratt, M.M., 2009. Retaining the next generation of nurses: the Wisconsin nurse residency program provides a continuum of support. Journal of Continuing Education in Nursing 40 (9), 416-425.

Campbell, S.L., Prater, M., Schwartz, C., Ridenour, N., 2001. Building an empowering academic and practice partnership model. Nursing Administration Quarterly 26 (1), 35-44.

Canadian Institute for Health Information, 2012. Regulated nurses: Canadian trends, 2006 to 2010. Retrieved April 30, 2012, https://secure.cihi.ca/free_products/RegulatedNursesCanadianTrends2006-2010_EN.pdf

Canadian Nurses Association, 2007. Tested solutions for eliminating Canada's registered nursing shortage. Retrieved December 14, 2011, http://www.cna-

nurses.ca/cna/documents/pdf/publications/RN_Highlights_e.pdf

Casey, K., Fink, R., Krugman, M., Propst, J., 2004. The graduate nurse experience. The Journal of Nursing Administration 34 (6), 303-311.

Clark, T., Holmes, S., 2007. Fit for practice? an exploration of the development of newly qualified nurses using focus groups. International Journal of Nursing Studies 44 (7), 1210-1220.

College of Registered Nurses of British Columbia, 2009. Competencies in the context of entry-level registered nurse practice in British Columbia. Retrieved December 14, 2011, https://www.crnbc.ca/Registration/Lists/RegistrationResources/375CompetenciesEntrylevelRN.pd f

Cooper, H.M., 1989. The integrative research review: a systematic approach. Sage, Newbury Park. Del Bueno, D., 2005. A crisis in critical thinking. Nursing Education Perspectives, 26 (5), 278-282.

Ellerton, M.L., Gregor, F., 2003. A study of transition: the new nurse graduate at 3 months. Journal of Continuing Education in Nursing 34 (3), 103-137.

Evans, J., 2008. The strengths and weaknesses of transition support programs for newly registered nurses. Australian Journal of Advanced Nursing 25 (4), 16-22. 
Facione, P., Blohm, S., Facione, N., Giancarlo, C., 1998. Professional judgment rating form:

novice/internship level critical thinking abilities and habits of mind. California Academic Press, Millbrae.

Fink, R., Krugman, M., Casey, K., Goode, C., 2008. The graduate nurse experience: qualitative residency program outcomes. The Journal of Nursing Administration 38 (7-8), 341-348.

Forneris, S.G., Peden-McAlpine, C., 2009. Creating context for critical thinking in practice: the role of the preceptor. Journal of Advanced Nursing 65 (8), 1715-1724.

Fox, K.C., 2010. Mentor program boosts new nurses' satisfaction and lowers turnover rate. Journal of Continuing Education in Nursing 41 (7), 311-316.

Gavlak, S., 2007. Centralized orientation: retaining graduate nurses. Journal for Nurses in Staff Development 23 (1), 26-30.

Goode, CJ, Lynn, MR, Krsek, C and Bednash, GD, 2009. Nurse residency programs: an essential requirement for nursing. Nursing Economics 27(3), 142-147, 159.

Goh, K., Watt, E., 2003. From 'dependent on' to 'depended on': the experience of transition from student to registered nurse in a private hospital graduate program. Australian Journal of Advanced Nursing 21 (1), 14-20.

Haffer, A.G., Raingruber, B.J., 1998. Discovering confidence in clinical reasoning and critical thinking development in baccalaureate nursing students. Journal of Nursing Education, 37 (2), 61-70.

Hayes, J.M., Scott, A.S., 2007. Mentoring partnerships as the wave of the future for new graduates. Nursing Education Perspectives 28 (1), 27-29.

Ho, B., 2006. Nurturing nurses. Registered Nurse 102 (9), 10-13.

Johnstone, M-J., Kanitsaki, O., Currie, T., 2008. The nature and implications of support in graduate nurse transition programs: an Australian study. Journal of Professional Nursing 24 (1), 46-53.

Kaddoura, M.A., 2010. New graduate nurses' perceptions of the effects of clinical simulation on their critical thinking, learning, and confidence. Journal of Continuing Education in Nursing 41 (11), 506-516.

Keller, J.L., Meekins, K., Summers, B.L., 2006. Pearls and pitfalls of a new graduate academic residency program. The Journal of Nursing Administration 36 (12), 589-598. 
Komaratat, S., Oumtanee, A., 2009. Using a mentorship model to prepare newly graduated nurses for competency. Journal of Continuing Education in Nursing 40 (10), 475-480.

Kowalski, S., Cross, C.L., 2010. Preliminary outcomes of a local residency programme for new graduate registered nurses. Journal of Nursing Management 18 (1), 96-104.

Kramer, M., 1974. Reality shock: why nurses leave nursing. Mosby, Saint Louis.

Kramer, M., Brewer, B. B., Maguire, P., 2011. Impact of Healthy Work Environments on New Graduate Nurses' Environmental Reality Shock. Western Journal of Nursing Research. DOI: $10.1177 / 0193945911403939$.

Krugman, M., Bretschneider, J., Horn, P.B., Krsek, C.A., Moutafis, R.A., Smith, M.O., 2006. The national post-baccalaureate graduate nurse residency program: a model for excellence in transition to practice. Journal for Nurses in Staff Development 22 (4), 196-205.

Lavoie-Tremblay, M., Wright, D., Desforges, N., Gelinas, C., Marchionni, C., Drevniok, U., 2008. Creating a healthy workplace for new-generation nurses. Journal of Nursing Scholarship 40 (3), 290-297.

Lee, T.Y., Tzeng, W.C., Lin, C.H., Yeh, M.L., 2009. Effects of a preceptorship programme on turnover rate, cost, quality and professional development. Journal of Clinical Nursing 18 (8), 1217-1225.

Leigh, J.A., Douglas, C.H., Lee, K., Douglas, M.R., 2005. A case study of a preceptorship programme in an acute NHS Trust - using the European Foundation for Quality Management tool to support clinical practice development. Journal of Nursing Management 13 (6), 508-518.

Levett-Jones, T., FitzGerald, M., 2005. A review of graduate nurse transition programs in Australia. Australian Journal of Advanced Nursing 23 (2), 40-44.

Li, S., Kenward, K., 2006. A national survey of nursing education and practice of newly licensed nurses. JONA'S Healthcare Law, Ethics and Regulation 8 (4), 110-115.

Lofmark, A., Smide, B., Wikblad, K., 2006. Competence of newly-graduated nurses-a comparison of the perceptions of qualified nurses and students. Journal of Advanced Nursing 53 (6), 721-728.

Maben, J., Latter, S., Clark, J.M., 2006. The theory-practice gap: impact of professional-bureaucratic work conflict on newly qualified nurses. Journal of Advanced Nursing, 55 (4), 465-477.

Marcum, E.H., West, R.D., 2004. Structured orientation for new graduates: a retention strategy. Journal for Nurses in Staff Development 20 (3), 118-126. 
McKenna, L., Newton, J.M., 2008. After the graduate year: a phenomenological exploration of how new nurses develop their knowledge and skill over the first 18 months following graduation. Australian Journal of Advanced Nursing 25 (4), 9-15.

Meadows, C.A., 2009. Integrating new graduate nurses in home healthcare. Home Healthcare Nurse 27 (9), 561-568.

Mills, J.F., Mullins, A.C., 2008. The California Nurse Mentor Project: every nurse deserves a mentor. Nursing economic\$ 26 (5), 310-315.

Murphy, M., Petryshen, P., Read, N., 2004. Retaining and transferring nursing knowledge through a hospital internship program. Nursing Leadership 17 (2), 60-68.

National Center For Health Workforce Analysis, 2002. Projected supply, demand, and shortages of registered nurses: 2000-2020. Retrieved February 17, 2012, http://www.ahcancal.org/research_data/staffing/documents/registered_nurse_supply_demand.pdf

Nugent, E., 2008. Implementing changes in educational strategies based on orientation experiences of the new graduate. Journal for Nurses in Staff Development 24 (5), 13-18.

Park, M., and Jones, C.B., 2010. A retention strategy for newly graduated nurses. Journal for Nurses in Staff Development 26 (4), 142-149.

Pickens, J.M., Fargotstein, B.P., 2006. Preceptorship: a shared journey between practice and education. Journal of Psychosocial Nursing and Mental Health Services 44 (2), 31-36.

Pine, R., and Tart, K., 2007. Return on investment: benefits and challenges of a Baccalaureate nurse residency program. Nursing Economics 25 (1), 13-39

Ramritu, P.L., Barnard, A., 2001. New nurse graduates' understanding of competence. International Nursing Review 48 (1), 47-57.

Roche, J.P., Lamoureux, E., Teehan, T., 2004. A partnership between nursing education and practice: using an empowerment model to retain new nurses. The Journal of Nursing Administration 34 (1), 26-32.

Romyn, D., Linton, N., Giblin, C., Hendrickson, B., Limacher, L.M., Murray, C., Nordstrom, P., Thauberger, G., Vosburgh, D., Vye-Rogers, L., Weidner, A., Zimmel, C.M., 2009. Successful 
transition of the new graduate nurse. International Journal of Nursing Education Scholarship 6 (1), 1-17.

Roxburgh, M., Lauder, W., Topping, K., Johnson, M., Watson, R. (2010). Early findings from an evaluation of a post-registration staff development programme: The Flying Start NHS Initiative in Scotland, UK. Nurse Education in Practice 10 (2), 76-81.

Rydon, S.E., Rolleston, A., Mackie, J., 2008. Graduates and initial employment. Nurse Education Today $28(5), 610-619$.

Schoessler, M., Waldo, M., 2006. Organizational infrastructure to support development of newly graduated nurses. Journal for Nurses in Staff Development 22 (6), 286-293.

Scott, E.S., Engelke, M.K., Swanson, M., 2008. New graduate nurse transitioning: necessary or nice? Applied Nursing Research 21 (2), 75-83.

Smith, J., Crawford, L., 2003. The link between perceived adequacy of preparation to practice, nursing error, and perceived difficulty of entry-level practice. JONA's Healthcare Law, Ethics, and Regulation 5 (4), 100-103.

Sorensen, H.A., Yankech, L.R., 2008. Precepting in the fast lane: improving critical thinking in new graduate nurses. Journal of Continuing Education in Nursing 39 (5), 208-216.

Spector, N., Echternacht, M., 2010. 2009 update on the National Council of Nursing's Regulatory Model for Transitioning New Nurses to Practice. JONA's Healthcare Law, Ethics and Regulation 12 (1), 12-14.

Strauss, M.B., 2009. Easing the transition: a successful new graduate program. Journal of Continuing Education in Nursing 40 (5), 216-220.

Uys, L.R., Van Rhyn, L.L., Gwele, N.S., Mclnerney, P., Tanga, T., 2004. Problem-solving competency of nursing graduates. Journal of Advanced Nursing 48 (5), 500-509.

Williams, C.A., Goode, C.J., Krsek, C., Bednash, G.D., Lynn, M.R., 2007. Postbaccalaureate nurse residency 1-year outcomes. The Journal of Nursing Administration 37 (7-8), 357-365.

Wolff, A., Pesut, B., Regan, S., 2010. New graduate nurse practice readiness: perspectives on the context shaping our understanding and expectations. Nurse Education Today 30 (2), 187-191. 
Young, M.E., Stuenkel, D.L., Bawel-Brinkley, K., 2008. Strategies for easing the role transformation of graduate nurses. Journal for Nurses in Staff Development 24 (3), 105-112.

Zucker, B., Goss, C., Williams, D., Bloodworth, L., Lynn, M., Denker, A., Gibbs, J.D., 2006. Nursing retention in the era of a nursing shortage: Norton Navigators. Journal for Nurses in Staff Development 22 (6), 302-306. 
Table 1. Summary of Studies

Study Descriptors

Program Elements

Outcomes

\begin{tabular}{|c|c|c|c|c|c|c|c|c|c|}
\hline \multicolumn{4}{|c|}{ Study Descriptors } & \multicolumn{4}{|c|}{ Program Elements } & \multicolumn{2}{|c|}{ Outcomes } \\
\hline Author(s) & $\begin{array}{l}\text { Level of } \\
\text { Evidence } \\
\text { Score }\end{array}$ & Design & $\begin{array}{l}\text { Sample } \\
\text { Size }\end{array}$ & $\begin{array}{l}\text { Transition } \\
\text { Program } \\
\text { Length } \\
\text { (months) }\end{array}$ & $\begin{array}{l}\text { Unit } \\
\text { Orientation } \\
\text { Length }\end{array}$ & $\begin{array}{l}\text { NG } \\
\text { Specific } \\
\text { Education }\end{array}$ & $\begin{array}{l}\text { Types of } \\
\text { supports } \\
\text { provided }\end{array}$ & $\begin{array}{l}\text { Competency } \\
\text { and Critical } \\
\text { Thinking }\end{array}$ & $\begin{array}{l}\text { Job } \\
\text { Satisfaction }\end{array}$ \\
\hline $\begin{array}{l}\text { Adlam, K. A., Dotchin, M., \& } \\
\text { Hayward, S. (2009) }\end{array}$ & 3 & Descriptive & - & - & - & & & - & - \\
\hline $\begin{array}{l}\text { Almada, P., Carafoli, K., Flattery, } \\
\text { J. B., French, D. A., \& McNamara, } \\
\text { M. (2004) }\end{array}$ & 3 & Descriptive & 40 & $>6$ months & $\begin{array}{l}>4 \text { weeks, } \\
\text { less than } 3 \\
\text { months }\end{array}$ & & $\begin{array}{l}\text { Mentor for } \\
\text { both } \\
\text { preceptor } \\
\text { and NG }\end{array}$ & - & $\uparrow$ \\
\hline Altier, M.E., \& Krsek, C.A. (2006) & 6 & Descriptive & 111 & $>6$ months & & Yes & $\begin{array}{l}\text { Resident } \\
\text { Facilitator }\end{array}$ & - & No change \\
\hline $\begin{array}{l}\text { Anderson, T., Linden, L., Allen, } \\
\text { M., \& Gibbs, E. (2009). }\end{array}$ & 6 & $\begin{array}{l}\text { Quasi- } \\
\text { experimental }\end{array}$ & 90 & $>6$ months & - & & & $\uparrow$ & $\downarrow$ \\
\hline $\begin{array}{l}\text { Applin, H., Williams, B., Day, R., } \\
\text { \& Buro, K. (2011) }\end{array}$ & 5 & Descriptive & 121 & & - & & & $\uparrow$ & - \\
\hline $\begin{array}{l}\text { Baggot, D. M., Hensinger, B., } \\
\text { Parry, J., Valdes, M. S., \& Zaim, S. } \\
\text { (2005) }\end{array}$ & 6 & Longitudinal & 526 & - & - & & & - & - \\
\hline $\begin{array}{l}\text { Beecroft, P., Hernandez, A. M., \& } \\
\text { Reid, D. (2008) }\end{array}$ & 5 & Descriptive & 88 & 4 - 6 months & $\begin{array}{l}>4 \text { weeks, } \\
\text { less than } 3 \\
\text { months }\end{array}$ & & & - & - \\
\hline $\begin{array}{l}\text { Beecroft, P. C., Santner, S., Lacy, } \\
\text { M. L., Kunzman, L., \& Dorey, F. } \\
(2006)\end{array}$ & 6 & Descriptive & 318 & - & - & & Mentor & - & - \\
\hline $\begin{array}{l}\text { Beyea, S., Kobokovich Van Reyn, } \\
\text { L., \& Slattery, M.J. (2007) }\end{array}$ & 4 & Longitudinal & 6 to 27 & $0-3$ & - & Yes & & $\uparrow$ & \\
\hline Bratt, M. M. (2009) & 5 & Descriptive & 1500 & $>6$ months & - & & $\begin{array}{l}\text { Mentor } \\
\text { (Clinical } \\
\text { Coach) }\end{array}$ & - & - \\
\hline $\begin{array}{l}\text { Blanzola, C., Lindeman, R., \& } \\
\text { King, M. L. (2004) }\end{array}$ & 5 & $\begin{array}{l}\text { Quasi- } \\
\text { experimental }\end{array}$ & 8 & 4 - 6 months & $<4$ weeks & Yes & Mentor & $\uparrow$ & - \\
\hline $\begin{array}{l}\text { Campbell, S. L., Prater, M., } \\
\text { Schwartz, C., \& Ridenour, N. } \\
(2001)\end{array}$ & 3 & Descriptive & - & - & - & Yes & & - & - \\
\hline
\end{tabular}


Table 1. Summary of Studies

Study Descriptors

Program Elements

Outcomes

\begin{tabular}{|c|c|c|c|c|c|c|c|c|c|}
\hline \multicolumn{4}{|c|}{ Study Descriptors } & \multicolumn{4}{|c|}{ Program Elements } & \multicolumn{2}{|c|}{ Outcomes } \\
\hline Author(s) & $\begin{array}{l}\text { Level of } \\
\text { Evidence } \\
\text { Score }\end{array}$ & Design & $\begin{array}{l}\text { Sample } \\
\text { Size }\end{array}$ & $\begin{array}{l}\text { Transition } \\
\text { Program } \\
\text { Length } \\
\text { (months) }\end{array}$ & $\begin{array}{l}\text { Unit } \\
\text { Orientation } \\
\text { Length }\end{array}$ & $\begin{array}{l}\text { NG } \\
\text { Specific } \\
\text { Education }\end{array}$ & $\begin{array}{l}\text { Types of } \\
\text { supports } \\
\text { provided }\end{array}$ & $\begin{array}{l}\text { Competency } \\
\text { and Critical } \\
\text { Thinking }\end{array}$ & $\begin{array}{l}\text { Job } \\
\text { Satisfaction }\end{array}$ \\
\hline $\begin{array}{l}\text { Casey, K., Fink, R., Krugman, M., } \\
\text { \& Propst, J. (2004) }\end{array}$ & 6 & Longitudinal & 270 & $>6$ months & - & Yes & $\begin{array}{l}\text { Resident } \\
\text { Facilitator }\end{array}$ & $\uparrow$ & - \\
\hline Clark, T., \& Holmes, S. (2007) & 5 & Qualitative & 110 & - & - & 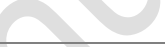 & & - & - \\
\hline $\begin{array}{l}\text { Ellerton, M. L., \& Gregor, F. } \\
(2003)\end{array}$ & 3 & Descriptive & 11 & $\begin{array}{l}\text { Mix of } 0-3 \\
\text { months and } 4 \\
-6 \text { months }\end{array}$ & $\begin{array}{l}\text { mix of }<4 \\
\text { weeks, and }> \\
4 \text { weeks but } \\
\text { less than } 3 \\
\text { months }\end{array}$ & Yes & & - & - \\
\hline $\begin{array}{l}\text { Fink, R., Krugman, M., Casey, K., } \\
\text { \& Goode, C. (2008) }\end{array}$ & 7 & Longitudinal & 434 & $>6$ months & - & Yes & $\begin{array}{l}\text { Resident } \\
\text { Facilitator }\end{array}$ & $\uparrow$ & - \\
\hline $\begin{array}{l}\text { Forneris, S. G., \& Peden- } \\
\text { McAlpine, C. (2009) }\end{array}$ & 3 & Qualitative & 12 & $>6$ months & - & & & $\uparrow$ & - \\
\hline Fox, K. C. (2010) & 3 & Descriptive & 24 & $>6$ months & - & & Mentor & - & $\uparrow$ \\
\hline Gavlak, S. (2007) & 5 & Descriptive & 126 & $0-3$ months & $<4$ weeks & & Mentor & - & - \\
\hline $\begin{array}{l}\text { Goode, C.J., Lynn, M.R., Krsek, C. } \\
\text { \& Bednash, G.D. (2009) }\end{array}$ & 7 & Longitudinal & 655 & $>6$ months & & Yes & $\begin{array}{l}\text { Resident } \\
\text { Facilitator }\end{array}$ & $\uparrow$ & \\
\hline Ho, B. (2006) & 3 & Descriptive & - & $>6$ months & - & & Mentor & - & - \\
\hline Hayes, J. M., \& Scott, A. S. (2007) & 3 & Descriptive & - & $0-3$ months & - & & $\begin{array}{l}\text { Single } \\
\text { mentor for } \\
\text { all residents }\end{array}$ & - & - \\
\hline Kaddoura, M. A. (2010) & 3 & Qualitative & 10 & & - & & & $\uparrow$ & - \\
\hline $\begin{array}{l}\text { Keller, J. L., Meekins, K., \& } \\
\text { Summers, B. L. (2006) }\end{array}$ & 3 & Descriptive & - & $>6$ months & - & & & - & - \\
\hline $\begin{array}{l}\text { Komaratat, S., \& Oumtanee, A. } \\
(2009)\end{array}$ & 5 & $\begin{array}{l}\text { Quasi- } \\
\text { experimental }\end{array}$ & 19 & 0 - 3 months & - & & Mentor & $\uparrow$ & - \\
\hline Kowalski, S., \& Cross, C. L. (2010) & 5 & Longitudinal & 55 & $>6$ months & $<4$ weeks & Yes & $\begin{array}{l}\text { Preceptor } \\
\text { continues } \\
\text { on in } \\
\text { mentor role }\end{array}$ & $\uparrow$ & - \\
\hline Kramer, M., Brewer, B. \& & 7 & Longitudinal & 371 & 4 - 6 months & & & & & \\
\hline
\end{tabular}


Table 1. Summary of Studies

Study Descriptors

\begin{tabular}{|c|c|c|c|c|c|c|c|c|c|}
\hline \multicolumn{4}{|c|}{ Stuay Descriptors } & \multicolumn{4}{|c|}{ Program Elements } & \multicolumn{2}{|c|}{ Uutcomes } \\
\hline Author(s) & $\begin{array}{l}\text { Level of } \\
\text { Evidence } \\
\text { Score }\end{array}$ & Design & $\begin{array}{l}\text { Sample } \\
\text { Size }\end{array}$ & $\begin{array}{l}\text { Transition } \\
\text { Program } \\
\text { Length } \\
\text { (months) }\end{array}$ & $\begin{array}{l}\text { Unit } \\
\text { Orientation } \\
\text { Length }\end{array}$ & $\begin{array}{l}\text { NG } \\
\text { Specific } \\
\text { Education }\end{array}$ & $\begin{array}{l}\text { Types of } \\
\text { supports } \\
\text { provided }\end{array}$ & $\begin{array}{l}\text { Competency } \\
\text { and Critical } \\
\text { Thinking }\end{array}$ & $\begin{array}{l}\text { Job } \\
\text { Satisfaction }\end{array}$ \\
\hline Maguire, P (2011) & & & & & & & $8-2$ & & \\
\hline $\begin{array}{l}\text { Krugman, M., Bretschneider, J., } \\
\text { Horn, P. B., Krsek, C. A., } \\
\text { Moutafis, R. A., \& Smith, M. O. } \\
\text { (2006) }\end{array}$ & 4 & Descriptive & - & $>6$ months & - & Yes & $\begin{array}{l}\text { Resident } \\
\text { Facilitator }\end{array}$ & - & $\uparrow$ \\
\hline $\begin{array}{l}\text { Lee, T. Y., Tzeng, W. C., Lin, C. H., } \\
\text { \& Yeh, M. L. (2009) }\end{array}$ & 6 & $\begin{array}{l}\text { Quasi- } \\
\text { experimental }\end{array}$ & 58 & $>6$ months & - & Yes & & - & - \\
\hline $\begin{array}{l}\text { Leigh, J. A., Douglas, C. H., Lee, } \\
\text { K., \& Douglas, M. R. (2005) }\end{array}$ & 5 & $\begin{array}{l}\text { Quasi- } \\
\text { experimental }\end{array}$ & 34 & $>6$ months & $<4$ weeks & & Mentor & $\uparrow$ & - \\
\hline Li, S., \& Kenward, K. (2006) & 5 & Descriptive & 7497 & - & - & & & - & - \\
\hline $\begin{array}{l}\text { Marcum, E. H., \& West, R. D. } \\
(2004)\end{array}$ & 5 & $\begin{array}{l}\text { Quasi- } \\
\text { experimental }\end{array}$ & 20 & 4 - 6 months & $<4$ weeks & Yes & Mentor & $\uparrow$ & - \\
\hline $\begin{array}{l}\text { McKenna, L., \& Newton, J. M. } \\
(2008)\end{array}$ & 3 & Qualitative & 24 & & - & & & - & - \\
\hline $\begin{array}{l}\text { Mills, J. F., \& Mullins, A. C. } \\
(2008)\end{array}$ & 3 & Descriptive & - & - & - & & Mentor & - & $\uparrow$ \\
\hline $\begin{array}{l}\text { Murphy, M., Petryshen, P., \& } \\
\text { Read, N. (2004) }\end{array}$ & 5 & Descriptive & 105 & $4-6$ months & - & Yes & & $\uparrow$ & $\uparrow$ \\
\hline Nugent, E. (2008) & 5 & Qualitative & 150 & $0-3$ months & $<4$ weeks & & & - & - \\
\hline $\begin{array}{l}\text { Pickens, J. M., \& Fargotstein, B. } \\
\text { P. (2006) }\end{array}$ & 3 & Descriptive & - & - & - & & & - & - \\
\hline Pine, R.,\& Tart, K. (2007) & 3 & Descriptive & 48 & $>6$ months & & Yes & $\begin{array}{l}\text { Resident } \\
\text { Facilitator }\end{array}$ & & \\
\hline $\begin{array}{l}\text { Roche, J. P., Lamoureux, E., \& } \\
\text { Teehan, T. (2004) }\end{array}$ & 4 & Descriptive & 67 & - & $\begin{array}{l}>4 \text { weeks, } \\
\text { less than } 3 \\
\text { months }\end{array}$ & & & - & - \\
\hline $\begin{array}{l}\text { Schoessler, M., \& Waldo, M. } \\
(2006)\end{array}$ & 3 & Descriptive & - & $>6$ months & - & Yes & & - & - \\
\hline $\begin{array}{l}\text { Scott, E. S., Engelke, M. K., \& } \\
\text { Swanson, M. (2008) }\end{array}$ & 5 & Descriptive & 329 & - & - & & & - & - \\
\hline Smith, J., \& Crawford, L. (2003) & 5 & Descriptive & 655 & - & - & & & - & - \\
\hline $\begin{array}{l}\text { Sorensen, H. A., \& Yankech, L. R. } \\
(2008)\end{array}$ & 5 & $\begin{array}{l}\text { Quasi- } \\
\text { experimental }\end{array}$ & 31 & 0 - 3 months & $\begin{array}{l}>4 \text { weeks, } \\
\text { less than } 3\end{array}$ & & & $\uparrow$ & - \\
\hline
\end{tabular}


Table 1. Summary of Studies

\begin{tabular}{|c|c|c|c|c|c|c|c|c|c|}
\hline \multicolumn{4}{|c|}{ Study Descriptors } & \multicolumn{4}{|c|}{ Program Elements } & \multicolumn{2}{|c|}{ Outcomes } \\
\hline Author(s) & $\begin{array}{l}\text { Level of } \\
\text { Evidence } \\
\text { Score }\end{array}$ & Design & $\begin{array}{l}\text { Sample } \\
\text { Size }\end{array}$ & $\begin{array}{l}\text { Transition } \\
\text { Program } \\
\text { Length } \\
\text { (months) }\end{array}$ & $\begin{array}{l}\text { Unit } \\
\text { Orientation } \\
\text { Length }\end{array}$ & $\begin{array}{l}\text { NG } \\
\text { Specific } \\
\text { Education }\end{array}$ & $\begin{array}{l}\text { Types of } \\
\text { supports } \\
\text { provided }\end{array}$ & $\begin{array}{l}\text { Competency } \\
\text { and Critical } \\
\text { Thinking }\end{array}$ & $\begin{array}{l}\text { Job } \\
\text { Satisfaction }\end{array}$ \\
\hline & & & & & months & & $8+2$ & & \\
\hline Strauss, M. B. (2009) & 3 & Descriptive & - & $0-3$ months & $\begin{array}{l}>4 \text { weeks, } \\
\text { less than } 3 \\
\text { months }\end{array}$ & Yes & $\begin{array}{l}\text { Program } \\
\text { Coordinator }\end{array}$ & - & - \\
\hline $\begin{array}{l}\text { Williams, C. A., Goode, C. J., } \\
\text { Krsek, C., Bednash, G. D., \& } \\
\text { Lynn, M. R. (2007) }\end{array}$ & 6 & Descriptive & 679 & $>6$ months & - & Yes & $\begin{array}{l}\text { Resident } \\
\text { Facilitator }\end{array}$ & $\uparrow$ & $\uparrow$ \\
\hline $\begin{array}{l}\text { Young, M. E., Stuenkel, D. L., \& } \\
\text { Bawel-Brinkley, K. (2008) }\end{array}$ & 5 & $\begin{array}{l}\text { Quasi- } \\
\text { experimental }\end{array}$ & 23 & $0-3$ months & $\begin{array}{l}>4 \text { weeks, } \\
\text { less than } 3 \\
\text { months }\end{array}$ & Yes & & - & - \\
\hline $\begin{array}{l}\text { Zucker, B., Goss, C., Williams, D., } \\
\text { Bloodworth, L., Lynn, M., } \\
\text { Denker, A., \& Gibbs, J. D. (2006) }\end{array}$ & 3 & Descriptive & - & $>6$ months & (1) & & & - & - \\
\hline
\end{tabular}


Table 2.

\begin{tabular}{|c|c|c|c|c|c|c|c|c|c|}
\hline \multicolumn{10}{|l|}{ Retention and Turnover Rates } \\
\hline Reference & $\begin{array}{l}\text { Level of } \\
\text { Evidence } \\
\text { Score }\end{array}$ & Program type & $\begin{array}{c}\text { Program } \\
\text { length }\end{array}$ & $\begin{array}{l}\text { Study } \\
\text { sample } \\
\text { size }\end{array}$ & $\begin{array}{l}\text { Pre- } \\
\text { program } \\
\text { retention }\end{array}$ & $\begin{array}{l}\text { Post- } \\
\text { program } \\
\text { retention }\end{array}$ & $\begin{array}{c}\% \\
\text { change }\end{array}$ & $\begin{array}{l}\text { Time when } \\
\text { post-program } \\
\text { rate measured }\end{array}$ & Cost Benefit \\
\hline $\begin{array}{l}\text { Almada, Carafoli, Flattery, } \\
\text { French and McNamara } \\
\text { (2004) }\end{array}$ & 3 & Un-named & $12 \mathrm{mo}$. & 40 & $60 \%$ & $89 \%$ & $39 \%$ & $\begin{array}{l}\text { At } 14 \text { mo. post } \\
\text { implementation } \\
\text { of the program }\end{array}$ & \\
\hline Anderson and Linden (2009) & 6 & Residency & $12 \mathrm{mo}$. & 90 & $60 \%$ & $90 \%$ & $30 \%$ & $\begin{array}{l}\text { At one year post } \\
\text { hire }\end{array}$ & \\
\hline Leigh et al (2005) & 5 & Un-named & $12 \mathrm{mo}$. & $\begin{array}{c}\text { Not } \\
\text { provided }\end{array}$ & $76 \%$ & $99 \%$ & $23 \%$ & $\begin{array}{l}\text { At one year post } \\
\text { hire }\end{array}$ & $\begin{array}{l}\$ 186,102 \text { US six } \\
\text { months savings }\end{array}$ \\
\hline Marcum and West (2004) & 5 & Un-named & $9 \mathrm{mo}$. & 20 & $60 \%$ & $89 \%$ & $29 \%$ & $\begin{array}{l}\text { At } 18 \text { mo. post } \\
\text { completion of } \\
\text { the program }\end{array}$ & $\begin{array}{l}\$ 330,481 \text { US annual } \\
\text { return on investment }\end{array}$ \\
\hline $\begin{array}{l}\text { Zucker, Goss, Williams, } \\
\text { Bloodworth, Lynn, Denker, } \\
\text { and Gibbs (2006) }\end{array}$ & 3 & Mentorship & $18 \mathrm{mo}$. & $\begin{array}{l}\text { Not } \\
\text { provided }\end{array}$ & $77 \%$ & $90 \%$ & $13 \%$ & $\begin{array}{l}\text { At } 6 \text { mo. } \\
\text { program } \\
\text { implementation }\end{array}$ & \\
\hline \multicolumn{10}{|l|}{ Post-Program Retention Only } \\
\hline Altier and Krsek (2006) & 6 & Residency & $12 \mathrm{mo}$. & 111 & - & $87 \%$ & - & $\begin{array}{l}\text { At one year post } \\
\text { hire }\end{array}$ & \\
\hline Bratt (2009) & 5 & Residency & $15 \mathrm{mo}$. & 1,100 & - & $90 \%$ & - & $\begin{array}{l}15-18 \text { mo. post } \\
\text { program } \\
\text { completion }\end{array}$ & \\
\hline Gavlak (2007) & 5 & Un-named & $12 \mathrm{mo}$. & 120 & - & $94 \%$ & - & $\begin{array}{l}\text { At one year post } \\
\text { hire }\end{array}$ & \\
\hline $\begin{array}{l}\text { Keller, Meekins and } \\
\text { Summers (2006) }\end{array}$ & 3 & Residency & $12 \mathrm{mo}$. & 72 & - & $89 \%$ & - & $\begin{array}{l}\text { At one year post } \\
\text { hire }\end{array}$ & \\
\hline Kowalski and Cross (2010) & 5 & Residency & $12 \mathrm{mo}$. & 55 & - & $78 \%$ & - & $\begin{array}{l}\text { At one year post } \\
\text { hire }\end{array}$ & \\
\hline
\end{tabular}




\begin{tabular}{|c|c|c|c|c|c|c|c|c|c|}
\hline Mills and Mullins (2008) & 3 & Mentorship & $12 \mathrm{mo.}$ & $\begin{array}{c}\text { Not } \\
\text { provided }\end{array}$ & - & $\begin{array}{l}\text { Mentored } \\
=92 \% ; \\
\text { Control = } \\
77 \%\end{array}$ & - & $\begin{array}{l}\text { No exact point } \\
\text { provided, but } \\
\text { within one year } \\
\text { of hire }\end{array}$ & 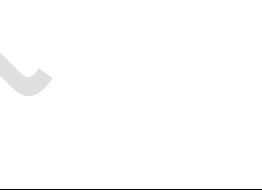 \\
\hline Strauss (2009) & 3 & Un-named & $3 \mathrm{mo}$. & $\begin{array}{c}\text { Not } \\
\text { provided }\end{array}$ & - & $97 \%$ & - & $\begin{array}{l}\text { At one year post } \\
\text { hire }\end{array}$ & \\
\hline \multicolumn{10}{|l|}{ Papers Using Turnover Rates } \\
\hline Reference & $\begin{array}{l}\text { Level of } \\
\text { Evidence } \\
\text { Score }\end{array}$ & Program type & $\begin{array}{l}\text { Program } \\
\text { length }\end{array}$ & $\begin{array}{l}\text { Study } \\
\text { sample } \\
\text { size }\end{array}$ & $\begin{array}{l}\text { Pre- } \\
\text { program } \\
\text { retention }\end{array}$ & $\begin{array}{l}\text { Post- } \\
\text { program } \\
\text { retention }\end{array}$ & $\begin{array}{c}\% \\
\text { change }\end{array}$ & $\begin{array}{l}\text { Time when } \\
\text { post-program } \\
\text { rate measured }\end{array}$ & Cost Benefit \\
\hline Fox (2010) & 3 & Mentorship & $12 \mathrm{mo}$. & 12 & $32 \%$ & $16 \%$ & $16 \%$ & $\begin{array}{l}\text { At one year post } \\
\text { hire }\end{array}$ & $\begin{array}{l}\$ 1,040,153 \text { US } \\
\text { annual savings }\end{array}$ \\
\hline Pine and Tart (2007) & 3 & Residency & $12 \mathrm{mo}$. & 48 & $50 \%$ & $13 \%$ & $37 \%$ & At one year & $\begin{array}{c}\$ 823,680 \text { US } \\
\text { annual savings }\end{array}$ \\
\hline $\begin{array}{l}\text { Schoessler and Waldo } \\
\text { (2006) }\end{array}$ & 3 & Un-named & $24 \mathrm{mo}$. & $\begin{array}{l}\text { Not } \\
\text { provided }\end{array}$ & $20 \%$ & $6 \%$ & $14 \%$ & $\begin{array}{l}3 \text { years post } \\
\text { program } \\
\text { implementation }\end{array}$ & \\
\hline \multicolumn{10}{|l|}{ Post Program Turnover Only } \\
\hline $\begin{array}{l}\text { Williams, Goode, and Krsek } \\
\text { (2007) }\end{array}$ & 6 & Residency & $12 \mathrm{mo}$. & 679 & - & $12 \%$ & - & $\begin{array}{l}\text { At one year post } \\
\text { hire }\end{array}$ & \\
\hline $\begin{array}{l}\text { Krugman, Bretschneider, } \\
\text { Horn, Krsek, Moutafis, and } \\
\text { Smith (2006) }\end{array}$ & 4 & Residency & $12 \mathrm{mo}$. & $\begin{array}{c}\text { Not } \\
\text { provided }\end{array}$ & - & $8 \%$ & - & $\begin{array}{l}\text { At one year post } \\
\text { hire }\end{array}$ & \\
\hline
\end{tabular}

